\title{
Effect of poultry litter application method on ammonia volatilization from a conservation tillage system
}

\author{
D.H. Pote and J.J. Meisinger
}

\begin{abstract}
Ammonia $\left(\mathrm{NH}_{3}\right)$ volatilization from agricultural fields is important economically as a direct loss of the valuable crop nutrient nitrogen $(\mathrm{N})$, but it can also be a significant environmental concern for soil, air, and water quality of nearby ecosystems. As poultry production has expanded in cropland areas of the southeastern United States, poultry litter has become a major source of crop nutrients for farmers using conservation tillage systems. However, the conventional application method of broadcasting poultry litter on the soil surface can allow as much as $60 \%$ of the applied litter $\mathrm{N}$ to volatilize as $\mathrm{NH}_{3}$. To provide management options that can prevent $\mathrm{NH}_{3}$ losses and help farmers use poultry litter nutrients more efficiently, a research team at USDA's Agricultural Research Service developed a prototype tractor-drawn implement for subsurface application of dry poultry litter in perennial pasture and conservation tillage systems. When compared to surface broadcasting, previous research showed that subsurface application of poultry litter decreased odor problems, increased crop yields, prevented more than $90 \%$ of nutrient losses in runoff, and prevented $\mathrm{NH}_{3}$ volatilization from perennial pasture systems. The current study was conducted to expand our knowledge regarding the effect of this litter application method on $\mathrm{NH}_{3}$ volatilization from row-crop conservation tillage systems. For two consecutive summers, field plots with a uniform high-residue surface cover of chopped wheat straw received about $5,000 \mathrm{~kg} \mathrm{ha}^{-1}\left(4,500 \mathrm{lb} \mathrm{ac}^{-1}\right)$ of poultry litter applied by surface spreading with no incorporation, surface spreading followed by light disking, or subsurface banding using the prototype USDA ARS applicator. Small mobile wind tunnels monitored $\mathrm{NH}_{3}$ volatilization for at least five days after each litter treatment. Results for both years showed that $\mathrm{NH}_{3}$ losses were consistently affected by diurnal variations that were closely related to the vapor pressure deficit. Compared to conventional surface spreading of poultry litter, $\mathrm{NH}_{3}$ volatilization decreased an average of $67 \%$ when the litter application was followed by light disking, and decreased an average of $88 \%$ when the litter was applied below the soil surface using the prototype applicator. These data show that subsurface injection of dry poultry litter can preserve adequate surface cover for conservation needs while constraining $\mathrm{NH}_{3}$ losses to minimal levels, thus conserving $\mathrm{N}$ for row crops and reducing potential nitrogen losses to the environment.
\end{abstract}

Key words: ammonia volatilization-conservation tillage-manure application methodmanure nitrogen loss - poultry litter-subsurface application

\begin{abstract}
Ammonia $\left(\mathrm{NH}_{3}\right)$ volatilization from agricultural fields is important economically to farmers because it is a direct loss of valuable plant-available nitrogen $(\mathrm{N})$. However, these $\mathrm{NH}_{3}$ emissions are also a significant environmental concern because they contribute to acid rain (Sharpe et al. 2004), soil acidification (van Breemen et al. 1982), and $\mathrm{N}$ enrichment of surface waters (Hutchinson and Viets 1969; Schroder 1985;
\end{abstract}

Fisher and Oppenheimer 1991). Ammonia is a chemically active gas that readily combines with nitrates and sulfates in the atmosphere to form fine particulate matter, which has been implicated in human respiratory problems and led to revised air quality standards in the United States (Dell et al. 2012; Sommer and Hutchings 2001). Ammonia loss can cause additional soil and water problems by decreasing the $\mathrm{N}$ :phosphorus $(\mathrm{P})$ ratio in manure and accelerating excessive soil $\mathrm{P}$ buildup (Meisinger and Jokela 2000) when farmers apply extra manure to compensate their crops for the $\mathrm{N}$ that was volatilized (Marshall et al. 1998). The excess soil P can be transported by runoff into nearby aquatic systems where it further accelerates the eutrophication process (Levine and Schindler 1989).

Several factors affect the rate at which $\mathrm{NH}_{3}$ is volatilized from animal manure applied to agricultural fields, including manure composition, soil factors, application method, surface cover, and environmental conditions (Meisinger and Randall 1991; Meisinger and Jokela 2000; Thompson and Meisinger 2002). For example, higher $\mathrm{NH}_{3}$ losses occur when the manure $\mathrm{pH}$ value is above 7 (Moore et al. 2011) and when environmental factors favor high evaporation rates (Brunke et al. 1988). Thompson and Meisinger (2002) found that $\mathrm{NH}_{3}$ losses from surface-applied dairy slurry were $45 \%$ for a grass surface, compared to $29 \%$ from bare soil. Pfluke et al. (2011) also spread liquid dairy manure on the surface of grass forage plots and observed during the following 36 hours that $\mathrm{NH}_{3}-\mathrm{N}$ volatilization ranged as high as $59 \%$ of total ammoniacal $\mathrm{N}$ (TAN) applied, but found that surface banding the manure decreased losses significantly compared to the broadcast method. In fact, application method has often been identified as the most important factor for preventing $\mathrm{NH}_{3}$ loss. For example, Thompson et al. (1987) found that $\mathrm{N}$ lost through $\mathrm{NH}_{3}$ volatilization decreased from $25 \%$ of the applied $\mathrm{N}$ to less than $1 \%$ when they injected cattle manure slurry into perennial grass plots rather than applying it on the surface. Several studies have shown that $\mathrm{NH}_{3}$ losses decrease as incorporation into the soil increases (Wulf et al. 2002; Thompson and Meisinger 2002; Hansen et al. 2003; Powell et al. 2011), decreasing as much as $99 \%$ when the slurry is injected beneath the surface (Dell et al. 2012), especially when injected at greater soil depths (Sommer and Hutchings 2001).

Daniel H. Pote is a soil scientist for USDA Agricultural Research Service at the Dale Bumpers Small Farms Research Center in Booneville, Arkansas. John J. Meisinger is a soil scientist and research leader at the Environmental Management and Byproduct Utilization Laboratory of USDA Agricultural Research Service in Beltsville, Maryland. 
Poultry litter is a mixture of manure and bedding material that accumulates on the floor of commercial poultry houses and is generally removed after the birds have gone to market. This solid by-product of poultry production is an excellent organic source of crop nutrients and is usually applied to the soil as fertilizer (Cabrera and Chiang 1994). It contains approximately $30 \%$ organic carbon (C) and significant quantities of primary plant nutrients (N, P, and potassium $[\mathrm{K}]$ ), but also provides secondary nutrients (calcium $[\mathrm{Ca}]$, magnesium $[\mathrm{Mg}]$, and sulfur $[\mathrm{S}]$ ) and micronutrients (copper $[\mathrm{Cu}]$, iron $[\mathrm{Fe}]$, manganese [Mn], zinc [Zn], and boron [B]). Furthermore, poultry manure often contains sufficiently high concentrations of $\mathrm{Ca}$ and $\mathrm{Mg}$ to help neutralize high soil acidity, thereby decreasing or eliminating the need for applications of agricultural lime. Because of these characteristics, especially its high $\mathrm{N}$ content, well-managed poultry manure is considered the most valuable of all livestock manures for increasing soil fertility (Mitchell and Donald 1995).

Poultry production has become a leading agricultural enterprise in many areas of the southeastern United States, a region where high annual temperatures combine with relatively high rainfall to produce highly weathered soils and rapid decomposition of plant residues needed for soil cover and erosion control. As a result, perennial pastures and conservation tillage systems that help conserve soil $\mathrm{C}$ and prevent erosion losses now dominate the agricultural landscape in much of the region. Poultry litter generated there has been used primarily to convert poor or marginal agricultural soils into highly productive perennial pastures and hay fields. As poultry production has expanded in cropland areas, poultry litter has also become a major source of nutrients for southeastern farmers using conservation tillage systems to produce annual crops such as wheat (Triticum aestivum L.) and corn (Zea mays L.) (Pote et al. 2011).

Ammonia volatilization from litter in commercial poultry houses increases as water content of the litter increases, so it is recommended that litter be kept dry to reduce $\mathrm{N}$ losses (Cabrera and Chiang 1994). Unfortunately, existing farm equipment can only apply poultry litter in conservation tillage and no-till systems by broadcasting it on the soil surface. This method leaves the litter exposed to the atmosphere, allowing substantial $\mathrm{NH}_{3}$ volatilization (Brady 1990; Chapman and Snyder 1992; Nathan and Malzer 1994; Sharpe et al. 2004), as well as nutrient losses in runoff (Edwards and Daniel 1993; Pote et al. 2003). Research has shown that $\mathrm{N}$ losses through $\mathrm{NH}_{3}$ volatilization from surface-applied poultry litter can reach as high as $60 \%$ of total $\mathrm{N}$ applied, depending on litter characteristics and environmental factors (Brinson et al. 1994; Cabrera et al. 1993; Cabrera and Chiang 1994; Marshall et al. 1998). As a result, researchers have estimated that approximately $27 \%$ of all $\mathrm{NH}_{3}$ emissions in the United States originate from poultry manure (Battye et al. 1994; Moore et al. 2011).

To provide management options that can help prevent $\mathrm{NH}_{3}$ losses and allow farmers to use poultry litter nutrients more efficiently, a research team at USDA's Agricultural Research Service developed the Subsurfer (figure 1). The Subsurfer is a prototype tractor-drawn implement for subsurface application (injection) of dry poultry litter $(<25 \%$ moisture) in no-till systems. When compared to conventional surface spreading of poultry litter, studies have shown that the Subsurfer technology can decrease odor problems, prevent more than $90 \%$ of nutrient losses in runoff events that follow litter applications, and increase crop yields (Pote et al. 2011). Research has also shown that subsurface application of poultry litter can prevent more than $97 \%$ of $\mathrm{NH}_{3}$ loss from perennial grassland (Moore et al. 2011; Pote et al. 2011), but the effectiveness of this technology for preventing $\mathrm{NH}_{3}$ volatilization from conservation tillage systems has not been previously studied. Therefore, a two-year research project was conducted to determine the effect of litter application method on the rate of $\mathrm{NH}_{3}$ volatilization from dry poultry litter applied to a high-residue conservation tillage system.

\section{Materials and Methods}

Study Area. The studies evaluating poultry litter application methods were conducted from August 1 to August 6, 2008, and July 27 to August 1, 2009, at the South

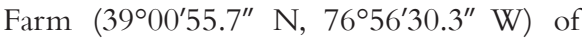
the USDA Agricultural Research Service Beltsville Agricultural Research Center in Beltsville, Maryland. The surface soil is a loam texture (35\% sand, $45 \%$ silt, and 20\% clay) with an internal drainage classified as moderately well-drained. The soil is classified as a Codorus silt loam (fine-loamy, mixed, active mesic, Typic Fluvaquentic Dystrudepts), and relevant properties of the 0 to $10 \mathrm{~cm}(0$ to 4 in) soil include a $\mathrm{pH}$ of 6 (1:1 in water), $0.95 \mathrm{~g}$ total $\mathrm{N} \mathrm{kg}^{-1}, 11.01 \mathrm{~g}$ total $\mathrm{C} \mathrm{kg}^{-1}$, cation exchange capacity (CEC) of $14.5 \mathrm{cmol} \mathrm{kg}^{-1}$ $\left(0.145 \mathrm{meq} \mathrm{g}^{-1}\right)$, bulk density of $1.35 \mathrm{~g} \mathrm{~cm}^{-3}$ $\left(84.3 \mathrm{lbs} \mathrm{ft}^{-3}\right)$, and field capacity water content of $250 \mathrm{~g} \mathrm{~kg}^{-1}$ (Thompson and Meisinger 2002).

Weather data were collected continuously throughout each study using a Campbell Scientific model UT-10 weather station located about $20 \mathrm{~m}(66 \mathrm{ft})$ from the study area. Weather variables of air temperature, rainfall, wind speed and direction, and relative humidity ( $\mathrm{RH})$ were collected from instruments located $1.5 \mathrm{~m}$ (4.9 ft) above the soil with observations taken every $10 \mathrm{sec}-$ onds, and variable averages or totals stored every 15 minutes. The weather variables for each morning, afternoon, or overnight exposure was calculated by averaging each variable over the exposure time interval. Vapor pressure deficit (VPD) of each exposure was also calculated from the relative humidity and air temperature according to equation 2A in table 1 of Howell and Dusek (1995), which multiplies the saturated vapor pressure of the average temperature by (1 $\mathrm{RH}$ [as a decimal]).

Analysis of the poultry litter involved bulking at least 10 random samples into a composite sample, mixing the composite sample, and then randomly selecting an analytical sample from composite mixture. The litter from each year was analyzed in triplicate for moisture (overnight drying at $105^{\circ} \mathrm{C}$ $\left.\left[221^{\circ} \mathrm{F}\right]\right), \mathrm{pH}$ (specific ion electrode on a1:2, litter:water, slurry), total $\mathrm{N}$ (automated Dumas combustion), and ammonium-N $\left(\mathrm{NH}_{4}-\mathrm{N}\right.$; specific ion electrode) as described in detail by Peters et al. (2003).

Ammonia Volatilization Measurements. In-field $\mathrm{NH}_{3}$ volatilization was measured using a system of small mobile wind tunnels described in detail by Meisinger et al. (2000), which updated the original Lockyer (1984) system. Briefly, the small wind tunnels consist of two connected parts: (1) an open-ended transparent polycarbonate canopy secured to a $1 \mathrm{~m}^{2}\left(11 \mathrm{ft}^{2}\right)$ base frame $(0.5 \times 2.0 \mathrm{~m}[1.6$ $\times 6.6 \mathrm{ft}])$ that is placed on the surface to produce an inverted "U-shaped" open-ended tunnel covering the treated area, and (2) an attached $40 \mathrm{~cm}$ (16 in) diameter cylindrical sheet metal air duct that houses an adjustable speed motor with fan blade, a cross-sectional air sampler, and a thermal anemometer to 
monitor total air flow through the tunnel. To estimate $\mathrm{NH}_{3}$ volatilization, $\mathrm{NH}_{3}$ concentration in the air entering the plastic canopy is determined by measuring the air flow entering an inlet acid-trap with a calibrated flow-meter and trapping the $\mathrm{NH}_{3}$ in an inlet gas-washing bottle containing $10 \mathrm{mM}$ phosphoric acid $\left(\mathrm{H}_{3} \mathrm{PO}_{4}\right)$. The $\mathrm{NH}_{3}$ concentration in the air exiting the canopy is similarly measured with the cross-sectional air sampler in the sheet metal air duct that continuously passes a known volume of air, measured with a calibrated flow-meter, through an outlet gas-washing bottle containing $10 \mathrm{mM} \mathrm{H}_{3} \mathrm{PO}_{4}$. Ammonia volatilization is then estimated by calculating the difference in $\mathrm{NH}_{3}$ concentration in the exiting vs. incoming air and multiplying by the total air flow through the air duct section as measured by the calibrated thermal anemometer and recorded by a Campbell 21-X data logger using a 10 second sampling interval. A complete description of the construction, calibration, operation, and $\mathrm{NH}_{3}$ validation for these wind tunnels is given in Meisinger et al. (2000).

Ammonia loss measurements were begun quickly after litter application and continued for six days in 2008 and five days in 2009. The sampling procedure divided each day into a morning exposure from early morning to midday, an afternoon exposure from midday to evening, and an overnight exposure from evening until the following early morning. The procedure for each exposure was to record the time and the flow rate for each flow meter, remove the exposed $10 \mathrm{mM}$ $\mathrm{H}_{3} \mathrm{PO}_{4}$ gas-washing bottle, attach a new bot-

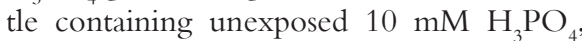
adjust the flow meters to their target flow rate if needed (inlets $5 \mathrm{~L} \mathrm{~min}^{-1}\left[0.18 \mathrm{ft}^{3} \mathrm{~min}^{-}\right.$ $\left.{ }^{1}\right]$, outlets at $\left.6 \mathrm{~L} \min ^{-1}\left[0.21 \mathrm{ft}^{3} \mathrm{~min}^{-1}\right]\right)$, and adjust the wind tunnel fans to nominal air flow rates of $1.0 \mathrm{~m} \mathrm{~s}^{-1}$ (2.2 $\mathrm{mph}$ ) during the morning and afternoon exposures or $0.5 \mathrm{~m}$ $\mathrm{s}^{-1}(1.1 \mathrm{mph})$ for the overnight exposures. This $24 \mathrm{~h} \mathrm{~d}^{-1}$ continuous monitoring procedure was followed until the last day of each study, when the study was terminated after the midday to evening exposure. The sampling protocol provided data for estimating total $\mathrm{NH}_{3}$ loss over the entire five or six day sampling period, and the $\mathrm{NH}_{3}$ loss rates per hour to estimate daily diurnal variations in $\mathrm{NH}_{3}$ loss.

The exposed $\mathrm{H}_{3} \mathrm{PO}_{4}$ was taken to a nearby laboratory and diluted to a known vol-

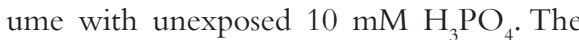
$\mathrm{NH}_{4}-\mathrm{N}$ concentration was determined with a Dionex model DX120 ion chromatograph equipped with a conductivity detector, a CG12A guard column, and a CS12A analytical column by injecting a $25 \mu \mathrm{L}\left(0.002 \mathrm{in}^{3}\right)$ sample into the $11 \mathrm{mM}$ sulfuric acid $\left(\mathrm{H}_{2} \mathrm{SO}_{4}\right)$ eluent stream that had a flow rate of $1 \mathrm{~mL}$ $\min ^{-1}\left(0.06 \mathrm{in}^{3} \mathrm{~min}^{-1}\right)$.

Poultry Litter Application Treatments. Several days before each study, the site was mowed and tilled with a heavy-duty tandem disk to produce a level low-residue surface soil. This low-residue surface was then converted to a uniform high-residue surface by applying chopped wheat straw the day before each study, using a straw chopper-blower that shredded and blew a known mass of wheat straw onto a known area. The chopped straw was applied at $5,500 \mathrm{~kg} \mathrm{ha}^{-1}\left(4,900 \mathrm{lb} \mathrm{ac}^{-1}\right)$ in 2008 and $5,400 \mathrm{~kg} \mathrm{ha}^{-1}\left(4,800 \mathrm{lb} \mathrm{ac}^{-1}\right)$ in 2009. The straw was added to provide a high-residue surface for the $\mathrm{NH}_{3}$ loss measurements that would mimic a surface under conservation-tillage and to allow measurement of the reduction of residue cover for each application method. Surface residue cover was determined using the line-intersect method (Morrison et al. 1993) that counted at least 150 points spaced $15 \mathrm{~cm}$ (6 in) apart on lines running at a 45 degree angle from the direction of implement travel.

The prototype poultry litter injector known as a Subsurfer (figure 1) has been described in more detail by Pote et al. (2011). Briefly, it uses a patented internal auger system to distribute a steady flow of dry, untreated poultry litter from a $4,540 \mathrm{~kg}$ $(10,000 \mathrm{lb})$ hopper capacity to eight shallow, parallel soil trenches simultaneously. Each of the eight soil-cutting attachments utilizes a conventional no-till technique to open the soil trenches, with a leading fluted coulter to slice the surface, followed by a double-disk trench opener. Litter drops through a chute into a trench formed between a set of double disks, and the soil surface is closed again by press wheels (figure 2). The technique is very effective for minimizing disturbance of the soil surface, with soil tillage intensity rating (STIR) values less than 3, well below the maximum STIR value (10 in Maryland) for the no-till classification that indicates the lowest levels of fuel consumption and carbon dioxide $\left(\mathrm{CO}_{2}\right)$ emission. The Subsurfer was calibrated by engaging the litter grinding and delivery mechanisms and driving over a $120 \mathrm{~cm}(4 \mathrm{ft})$ long tarpaulin with the injection units raised so the litter that would normally be injected fell on the tarpaulin. The collected litter was weighed and the tractor speed or the litter delivery rate adjusted until the desired application rate of approximately $5,000 \mathrm{~kg} \mathrm{ha}^{-1}\left(4,460 \mathrm{lb} \mathrm{ac}^{-1}\right)$ was achieved. The final application rate is given in table 1 , and was achieved with a tractor speed of $0.9 \mathrm{~m} \mathrm{~s}^{-1}\left(2 \mathrm{mi} \mathrm{hr}^{-1}\right)$. The litter injectors were spaced $30 \mathrm{~cm}$ (12 in) apart and placed the litter about $7.6 \mathrm{~cm}$ ( 3 in) deep. After the litter was injected, the wind tunnel canopy was placed perpendicular to the injected channels with approximately $20 \mathrm{~cm}$ (8 in) of untreated area left at the canopy entrance to provide a buffer area to stabilize air flow before reaching the treated area (Meisinger et al. 2001).

The disk treatment was designed to provide a shallow mixing of the poultry litter with the surface layer of residue and soil, but without substantial reduction of residue cover. Consequently, the tandem disk was adjusted to till approximately 3 to $5 \mathrm{~cm}$ (1 to 2 in) deep and was pulled at $2.2 \mathrm{~m} \mathrm{~s}^{-1}$ $\left(5 \mathrm{mi} \mathrm{hr}^{-1}\right)$. This light disking maintained a relatively low STIR value of 19.5 , classified as conservation tillage but still above the maximum STIR value for the no-till classification in Maryland. Prior to disk tillage, a firmly staked area $80 \times 180 \mathrm{~cm}(31.5 \times$ 70.9 in) was marked off and received a uniform manual application of poultry litter at the rate given in table 1 . The disk tillage ran parallel to the $180 \mathrm{~cm}$ dimension of the treated area. Immediately after tillage, a wind tunnel canopy was placed over the litter-treated area to enclose $50 \times 180 \mathrm{~cm}(19.7$ $\times 70.9$ in), leaving about $20 \mathrm{~cm}$ (8 in) as an untreated area to stabilize the incoming air flow. The litter-treated area along the sides of the canopy was manually tilled into the soil and covered with untreated soil to confine the $\mathrm{NH}_{3}$ emission source to the area under the canopy. After canopy placement, the sheet metal duct section was attached, and $\mathrm{NH}_{3}$ emission measurements commenced as described above.

The unincorporated surface treatment was included as a high-loss control that documented the potential $\mathrm{NH}_{3}$ loss from an untreated surface application. First a $50 \times$ $180 \mathrm{~cm}(19.7 \times 70.9 \mathrm{in})$ area was marked off, followed by manual application of poultry litter according to the rate given in table 1 . Immediately after litter application, a wind tunnel canopy was placed over the 


\section{Figure 1}

Prototype Subsurfer developed at USDA Agricultural Research Service, Booneville, Arkansas, for subsurface application of dry poultry litter in pasture and conservation tillage systems.

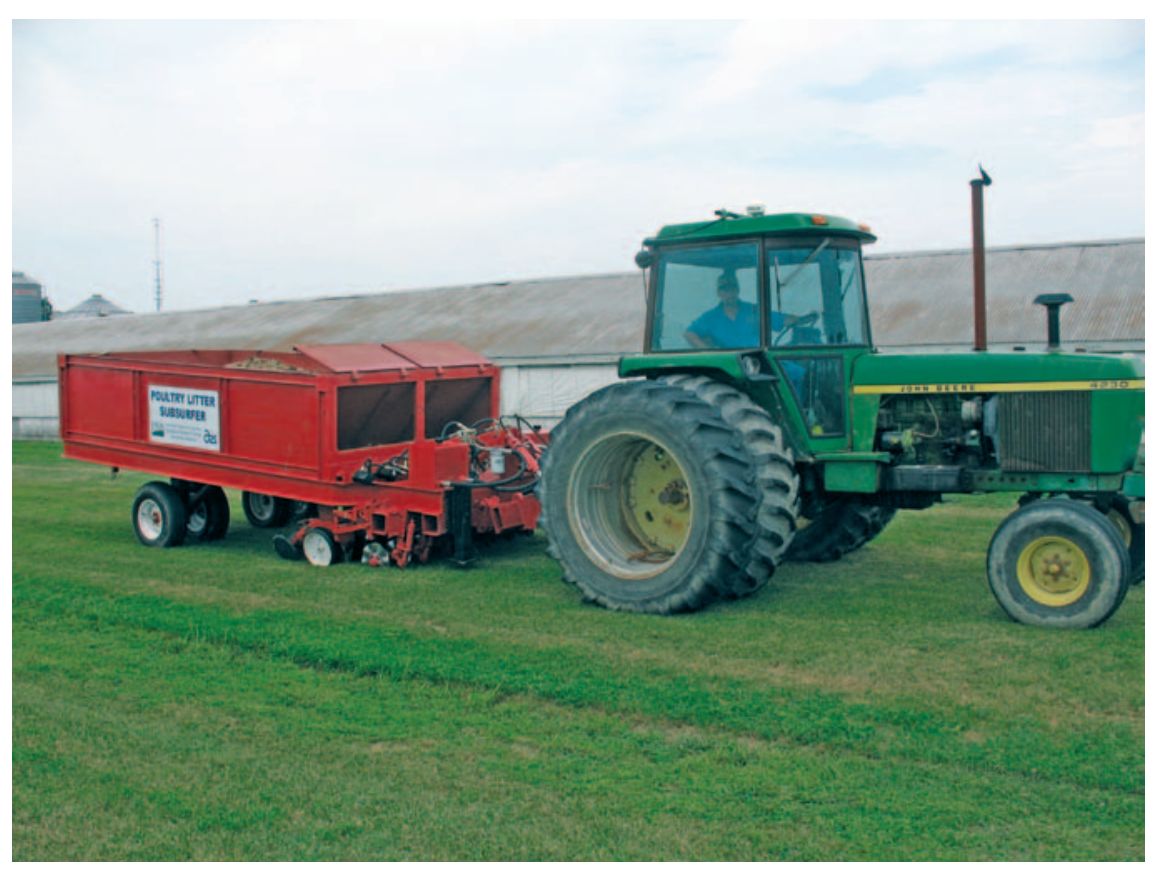

\section{Figure 2}

The prototype Subsurfer uses no-till technology to simultaneously apply eight parallel bands of dry poultry litter below the soil surface in a perennial pasture.

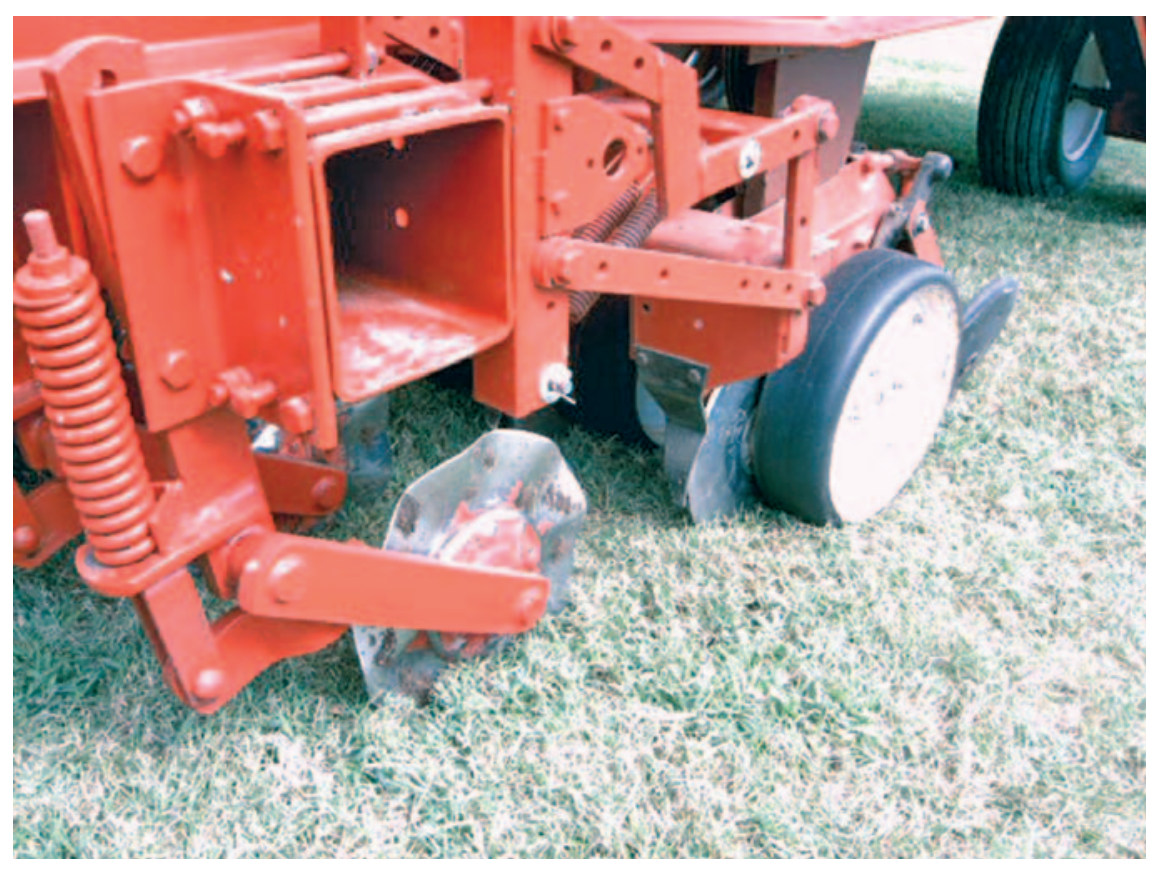

area, leaving $20 \mathrm{~cm}$ (8 in) of untreated area at the front of the canopy as above. The sheet metal duct was then attached, and $\mathrm{NH}_{3}$ emission measurements began.

Statistical Analysis. The limited number of wind tunnels available for each study dictated the need for compromise between number of replicates and number of treatments. We chose to emphasize treatment comparisons with limited replication. Accordingly, two treatments were duplicated in 2008 and one treatment was duplicated in 2009, but the new litter injection treatment was always duplicated. This approach has been commonly employed in studies using similar wind tunnel systems to examine $\mathrm{NH}_{3}$ volatilization, using either nonreplicated comparisons (Sommer and Olese 1991; Sommer et al. 1991; Thompson and Meisinger 2002) or limited replication with duplicates or triplicates (Moal et al. 1995; Pain et al. 1990; Sommer and Ersbøll 1994; Thompson and Meisinger 2002).

The wind tunnels were randomly assigned to a litter application treatment in the 2008 study with unequal replications, and were rerandomized again in the 2009 study with unequal replications. These two completely randomized designs are analyzed as two independent studies with the response variable being the total $\mathrm{NH}_{3}$ loss in each study expressed as the percentage of applied $\mathrm{NH}_{4}-\mathrm{N}$. The hourly rates of $\mathrm{NH}_{3}$ loss over each exposure were also calculated, and are summarized graphically over time for each application method (figures 3 and 4).

Statistical estimates of the variability of the total $\mathrm{NH}_{3}$ loss in this study were obtained by pooling variances among duplicated treatments, then determining if these estimates could be combined with similarly estimated variances reported by Thompson and Meisinger (2002), which used the same wind tunnels to measure $\mathrm{NH}_{3}$ volatilization from manure. The reported standard deviation (sd) from Thompson and Meisinger (2002) for the total $\mathrm{NH}_{3}-\mathrm{N}$ loss, as a percentage of applied $\mathrm{NH}_{4}-\mathrm{N}$, was $\pm 3.95 \%$, with 11 degrees of freedom (df). This previously reported sd was converted to a variance and tested for homogeneity with the corresponding variance from duplicates in this study using an $f$-test (Snedecor and Cochran 1980). The variances were found to be homogeneous and were consequently pooled, weighted by their df to produce an updated variance with a sd of $\pm 4.25 \%$ (14 


\section{Table 1}

Poultry litter compositions and application rates for litter injection studies.

\begin{tabular}{|c|c|c|c|c|c|c|c|}
\hline \multirow{2}{*}{$\begin{array}{l}\text { Study } \\
\text { Year }\end{array}$} & \multicolumn{4}{|c|}{ Litter compositions } & \multicolumn{3}{|c|}{ Litter application rates } \\
\hline & $\begin{array}{l}\text { Dry matter } \\
\text { (\% fresh weight) }\end{array}$ & $\begin{array}{l}\mathrm{NH}_{4}-\mathrm{N} \\
\text { (\% fresh weight) }\end{array}$ & $\begin{array}{l}\text { Total } N \\
\text { (\% fresh weight) }\end{array}$ & pH & $\begin{array}{l}\text { Rate } \\
\text { (litter, kg ha-1) }\end{array}$ & $\begin{array}{l}\text { Total N } \\
\left(\mathbf{k g ~ N ~ h a}^{-1}\right)\end{array}$ & $\begin{array}{l}\mathrm{NH}_{4}-\mathrm{N} \\
\left(\mathrm{kg} \mathrm{N} \mathrm{ha}^{-1}\right)\end{array}$ \\
\hline 2008 & 74.3 & 0.66 & 3.06 & 8.0 & 5,150 & 158 & 34 \\
\hline
\end{tabular}

Notes: $\mathrm{NH}_{4}-\mathrm{N}=$ ammonium-nitrogen. Total $\mathrm{N}=$ total nitrogen.

df) for the total $\mathrm{NH}_{3}-\mathrm{N}$ loss as a percentage of applied $\mathrm{NH}_{4}-\mathrm{N}$.

The variability among duplicate measurements of the hourly rate of $\mathrm{NH}_{3}$ volatilization was found to be correlated with the average rate of $\mathrm{NH}_{3}$ loss, a situation also encountered by Thompson and Meisinger (2002). Linear regression analysis of the sd of the $\mathrm{NH}_{3}$ volatilization rate versus the mean rate for each sampling interval gave a highly significant $(p$ $<0.01)$ relationship $\left(r^{2}=0.61\right)$ between the sd and mean. Consequently, rates of $\mathrm{NH}_{3}$ loss were separated into low-loss, medium-loss, and high-loss groups to allow pooling of similar variances and comparison of application methods. The pooled variances for a typical $6 \mathrm{hr}$ exposure for the low-loss group with a mean rate of $45 \mathrm{~g} \mathrm{NH}_{3}-\mathrm{N} \mathrm{ha}^{-1} 6 \mathrm{~h}^{-1}$ $\left(0.04 \mathrm{lb} \mathrm{NH}_{3}-\mathrm{N} \mathrm{ac}^{-1} 6 \mathrm{hr}^{-1}\right)$ produced a sd of $\pm 67 \mathrm{~g} \mathrm{NH}_{3}-\mathrm{N} \mathrm{ha}^{-1} 6 \mathrm{~h}^{-1}\left( \pm 0.06 \mathrm{lb} \mathrm{NH}_{3}-\mathrm{N}\right.$ $\left.\mathrm{ac}^{-1} 6 \mathrm{hr}^{-1}\right)$, the medium-loss group with a mean rate of $318 \mathrm{~g} \mathrm{NH}_{3}-\mathrm{N} \mathrm{ha}^{-1} 6 \mathrm{~h}^{-1}(0.28$ lb $\left.\mathrm{NH}_{3}-\mathrm{N} \mathrm{ac} \mathrm{ac}^{-1} 6 \mathrm{hr}^{-1}\right)$ had a sd of $\pm 253 \mathrm{~g}$ $\mathrm{NH}_{3}-\mathrm{N} \mathrm{ha}^{-1} 6 \mathrm{~h}^{-1}\left( \pm 0.23 \mathrm{lb} \mathrm{NH}_{3}-\mathrm{N} \mathrm{ac} \mathrm{ac}^{-1} 6\right.$ $\left.\mathrm{hr}^{-1}\right)$, and the high-loss group with a mean rate of $1,314 \mathrm{~g} \mathrm{NH}_{3}-\mathrm{N} \mathrm{ha}^{-1} 6 \mathrm{~h}^{-1}(1.17 \mathrm{lb}$ $\mathrm{NH}_{3}-\mathrm{N} \mathrm{ac}^{-1} 6 \mathrm{hr}^{-1}$ ) yielded a sd of $\pm 462 \mathrm{~g}$ $\mathrm{NH}_{3}-\mathrm{N} \mathrm{ha}^{-1} 6 \mathrm{~h}^{-1}\left( \pm 0.41 \mathrm{lb} \mathrm{NH}_{3}-\mathrm{N} \mathrm{ac}{ }^{-1} 6\right.$ $\left.\mathrm{hr}^{-1}\right)$; with each sd having $14 \mathrm{df}$. These sds provide a general measure of the uncertainties in the hourly $\mathrm{NH}_{3}-\mathrm{N}$ loss rates summarized in figures 3 and 4 .

\section{Results and Discussion}

Analyses of the poultry litter used in this study showed that moisture and $\mathrm{N}$ content were relatively consistent from one year to the next (table 1), considering the high degree of variability that often occurs between batches of poultry litter. Water content was approximately $260 \mathrm{~g} \mathrm{~kg}^{-1}$ in both years, while the $\mathrm{NH}_{4}-\mathrm{N}$ concentration varied only slightly from $6.6 \mathrm{~g} \mathrm{~N} \mathrm{~kg}^{-1}$ of litter to $6.4 \mathrm{~g} \mathrm{~N} \mathrm{~kg}^{-1}$ of litter, and for total $\mathrm{N}$ from $30.6 \mathrm{~g} \mathrm{~N} \mathrm{~kg}^{-1}$ of litter to $30.2 \mathrm{~g} \mathrm{~N} \mathrm{~kg}^{-1}$ of litter. In each year, the subsurface applicator was first used to apply approximately $5,000 \mathrm{~kg} \mathrm{ha}^{-1}(4,460$ $\mathrm{lb} \mathrm{ac}^{-1}$ ), and the exact rate applied was then matched manually for the disked and surface application treatments. Because the exact rate was slightly above the target rate in 2008 and slightly below it in 2009 , the total $\mathrm{N}$ applied to each treatment changed from $158 \mathrm{~kg} \mathrm{ha}^{-1}$ $\left(141 \mathrm{lb} \mathrm{ac}^{-1}\right)$ in 2008 to $142 \mathrm{~kg} \mathrm{ha}^{-1}(127 \mathrm{lb}$ $\left.\mathrm{ac}^{-1}\right)$ in 2009.

Both the injected and disk treatments significantly reduced the percentage of ground cover compared to the surface application treatment, but the injected and light-disking treatments were not significantly different from each other. The average ground cover for the injected and light-disk treatments was $82 \%$, which is an $18 \%$ reduction from the complete ground cover in the surface application treatment. Retaining $82 \%$ residue cover is consistent with the definition of conservation tillage $(>30 \%$ residue cover after planting) used by the Conservation Tillage Information Center (CTIC 2004). It also meets the more stringent Conservation Practice Standard for mulch tillage $>60 \%$ residue cover) recommended by the Natural Resources Conservation Service to reduce evaporation and increase plant-available moisture (USDA NRCS 2011).

Results for both years of the study showed that poultry litter application method had a strong impact on $\mathrm{NH}_{3}$ volatilization, and that rates of $\mathrm{NH}_{3}$ loss were very consistently affected by diurnal variations. When the $2008 \mathrm{NH}_{3}$ losses were examined incrementally over the course of six days (August 1 to 6) immediately following the litter applications (figure 3), it was apparent that $\mathrm{NH}_{3}$ volatilized primarily during the daylight hours when high temperatures ranged from $28^{\circ} \mathrm{C}$ to $31^{\circ} \mathrm{C}\left(82^{\circ} \mathrm{F}\right.$ to $\left.88^{\circ} \mathrm{F}\right)$. Diurnal variations in $\mathrm{NH}_{3}$ volatilization have also been observed in other studies (Sharpe et al. 2004; Brunke et al. 1988). In fact, Brunke et al. (1988) conducted further study of possible causes of the diurnal variation and reported that correlations of $\mathrm{NH}_{3}$ volatilization with temperature, solar radiation, and wind speed were generally high, but final conclusions were uncertain due to intercorrelations among the weather variables. In our study, the diurnal temperature variations (figure 3) were well matched to the $\mathrm{NH}_{3}$ emissions, but the $\mathrm{NH}_{3}$ losses virtually ceased during the overnight period when the temperatures were above $20^{\circ} \mathrm{C}\left(68^{\circ} \mathrm{F}\right)$. The fact that other researchers have found significant $\mathrm{NH}_{3}$ volatilization can occur at a wide range of temperatures, including temperatures below $15^{\circ} \mathrm{C}\left(59^{\circ} \mathrm{F}\right)$ (Sharpe et al. 2004; Pfluke et al. 2011), indicates that temperature per se is not likely to cause $\mathrm{NH}_{3}$ losses to virtually cease overnight. However, the VPD, which measures the dryness of the atmosphere with high VPD indicating dryer air (Howell and Dusek 1995), shows a pattern that is well matched to the $\mathrm{NH}_{3}$ emissions. For example, the VPD values decline to nearly zero during the overnight periods, which agrees with the negligible $\mathrm{NH}_{3}$ losses overnight. It seems likely that increasing ambient temperatures associated with radiant energy from the sun are not the primary driver for $\mathrm{NH}_{3}$ volatilization, but they are directly related to the VPD which allows ammonia to volatilize similar to the way that morning dew volatilizes when solar energy increases towards midday. Brunke et al. (1988) summarized their studies by stating that $\mathrm{NH}_{3}$ volatilization rates were consistent with the assumption that volatilization is primarily determined by atmospheric conditions that favor drying and suggested a derived meteorological variable (e.g., a hay-drying index) as a single indicator of high-volatilization weather conditions. Therefore, the generalizations of Brunke et al. (1988) and the data from this study are both consistent with the hypothesis that a measure of the atmospheric drying potential, such as theVPD, can be useful for identifying high-volatilization conditions.

Ammonia losses each day were much greater from surface-applied poultry litter that remained exposed to the atmosphere than from treatments where the litter had been partially or completely covered by disking or injecting it below the soil surface (figure 3). During the first day after the 2008 litter treatments were applied, $\mathrm{NH}_{3}-\mathrm{N}$ volatilized from the surface application at a rate of almost $1,300 \mathrm{~g} \mathrm{ha}^{-1} \mathrm{~h}^{-1}(1.2 \mathrm{lb}$ 
Figure 3

Diurnal pattern of (a) ammonia $\left(\mathrm{NH}_{3}-\mathrm{N}\right)$ volatilization rate, (b) vapor pressure deficit, and (c) temperature following poultry litter application by three methods in 2008.

(a)

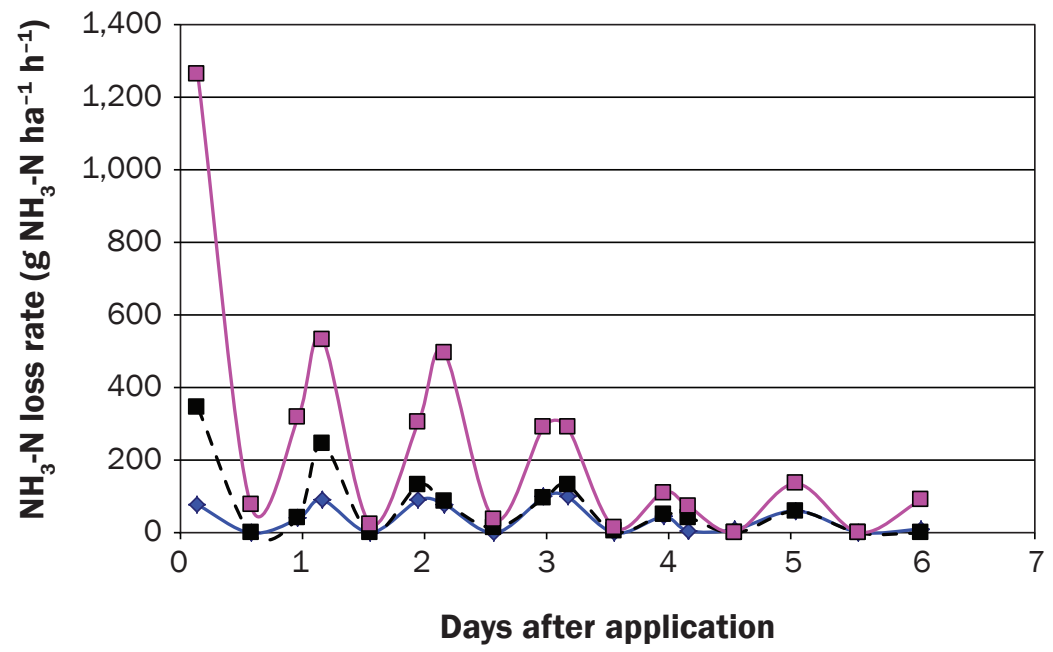

\section{Legend}

$\rightarrow$ Injected

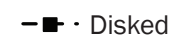

$\rightarrow-$ Surface

(b)

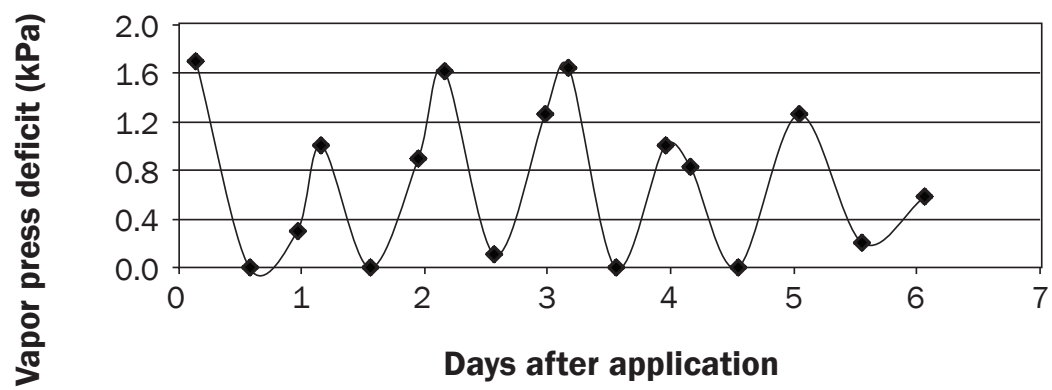

Legend

$\rightarrow$ Vapor pressure deficit

(c)

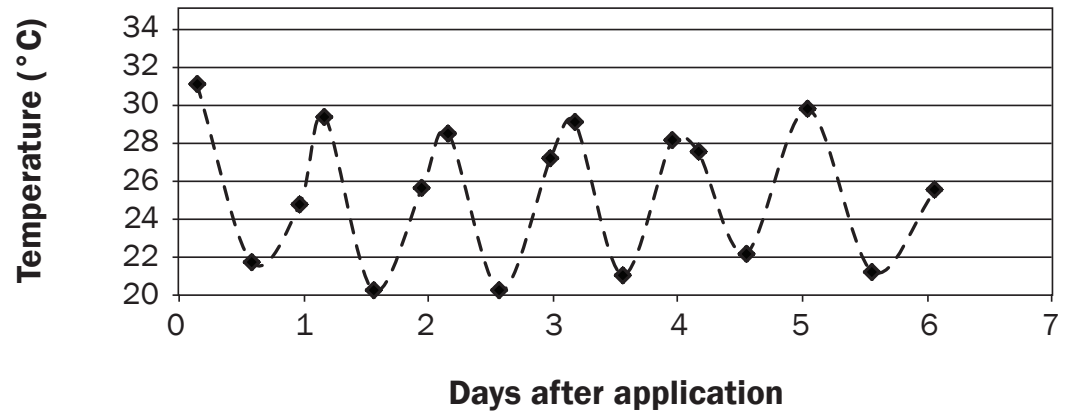

Legend

- Temperature
$\mathrm{NH}_{3}-\mathrm{N} \mathrm{ac}^{-1} \mathrm{hr}^{-1}$ ), which was approximately 16 times greater than the rate of $\mathrm{NH}_{3}$ loss from the subsurface application. However, the rate of $\mathrm{NH}_{3}-\mathrm{N}$ volatilization from surface litter had dropped to less than $600 \mathrm{~g} \mathrm{ha}^{-1}$ $\mathrm{hr}^{-1}\left(0.5 \mathrm{lb} \mathrm{NH}_{3}-\mathrm{N} \mathrm{ac}^{-1} \mathrm{hr}^{-1}\right)$ by the second day of monitoring, and the treatment differences decreased each day as cumulative losses removed most of the $\mathrm{NH}_{3}-\mathrm{N}$ from the surface litter, leaving smaller percentages available for further $\mathrm{NH}_{3}$ volatilization. By the fourth day after application of litter treatments, $\mathrm{NH}_{3}$ losses from surface litter were only about twice as high as losses from subsurface litter. This was very similar to the pattern of $\mathrm{NH}_{3}$ loss from surface-applied poultry manure that has been described by other researchers (Lockyer et al. 1989; Marshall et al. 1998; Sharpe et al. 2004).

Cumulative results showed that approximately $74 \%$ of $\mathrm{NH}_{4}-\mathrm{N}$ applied on the surface in 2008 was lost through volatilization within the first six days after the poultry litter application (table 2). Sharpe et al. (2004) reported $95 \%$ loss of $\mathrm{NH}_{4}-\mathrm{N}$ within an eight-day period immediately following surface application of poultry litter under similar summer conditions. Our results agree closely with the $\mathrm{NH}_{3}-\mathrm{N}$ loss estimates (80\% loss) from surface-applied litters listed by the University of Delaware and used for preparing nutrient management plans in Delaware, Pennsylvania, and Vermont (Meisinger and Jokela 2000).

In our study, disking the poultry litter into the soil decreased the losses to less than $22 \%$ of applied $\mathrm{NH}_{3}-\mathrm{N}$, while subsurface application (injection) was even more effective, allowing only about $12 \%$ of the $\mathrm{NH}_{3}-\mathrm{N}$ to volatilize. Therefore, overall $\mathrm{N}$ losses through $\mathrm{NH}_{3}$ volatilization in this study were more than six times as high from surface-applied litter than from subsurface (injected) litter.

In 2009, $\mathrm{NH}_{3}$ losses were monitored for five days (July 27 to August 1) and were examined incrementally by duplicating the 2008 protocol during that monitoring period (figure 4). The 2009 results showed similar trends to 2008 , as $\mathrm{NH}_{3}$ losses each day were much greater from surface-applied poultry litter that remained exposed to the atmosphere than from treatments where the litter had been partially or completely covered by disking or injecting it below the soil surface. The 2009 high temperatures ranged from $27^{\circ} \mathrm{F}$ to $31^{\circ} \mathrm{C}\left(81^{\circ} \mathrm{F}\right.$ to $\left.88^{\circ} \mathrm{F}\right)$, approximately the same as the high temperatures that occurred during the 2008 monitoring 


\section{Figure 4}

Diurnal pattern of (a) ammonia $\left(\mathrm{NH}_{3}-\mathrm{N}\right)$ volatilization rate, (b) vapor pressure deficit, and (c) temperature following poultry litter application by three methods in 2009.
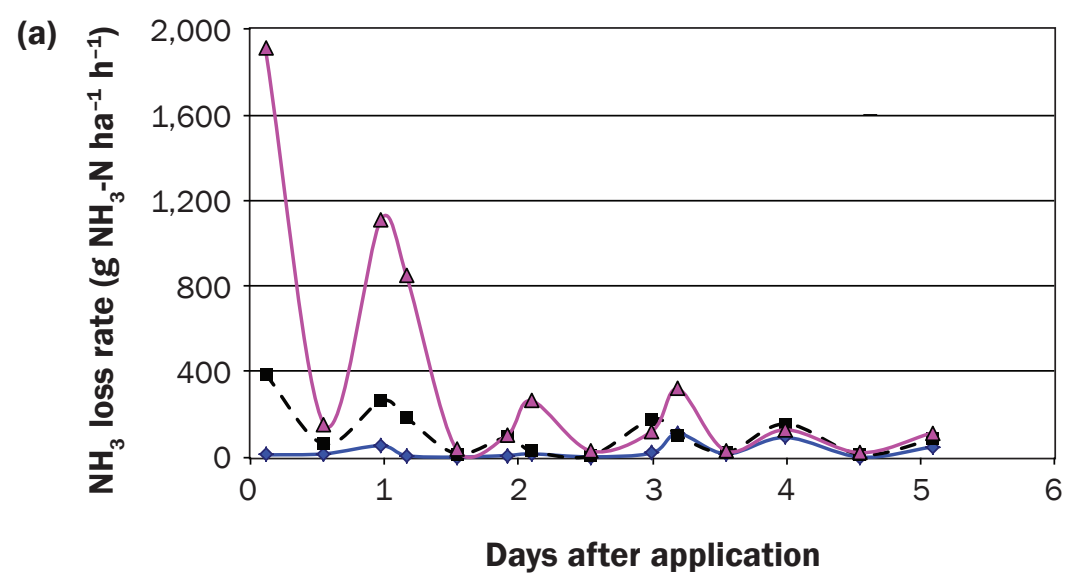

Legend

$\multimap$ Injected $\quad--\cdot$ Disked $\rightarrow$ Surface

(b)

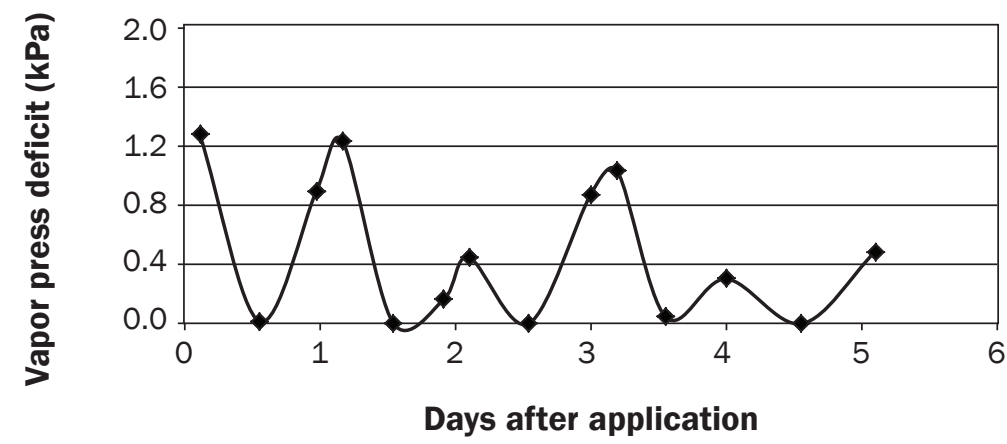

Legend

$\rightarrow$ Vapor pressure deficit

(c)

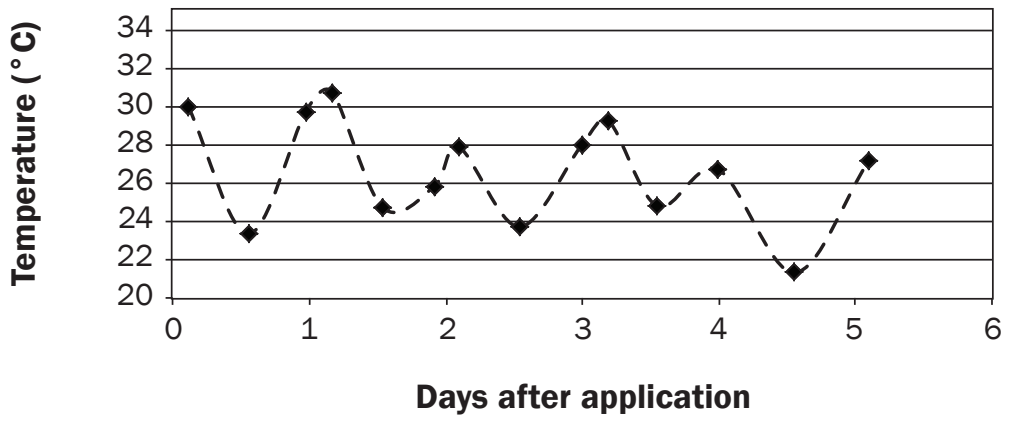

Legend

- - Temperature period. As expected, the 2009 incremental data again showed that $\mathrm{NH}_{3}$ volatilized primarily during the daylight hours when solar energy increased ambient temperatures and simultaneously increased VPDs. However, $\mathrm{NH}_{3}-\mathrm{N}$ volatilized from the 2009 surface application at a rate of approximately $1,900 \mathrm{~g}$ $\mathrm{ha}^{-1} \mathrm{~h}^{-1}\left(1.7 \mathrm{lb} \mathrm{NH}_{3}-\mathrm{N} \mathrm{ac}^{-1} \mathrm{hr}^{-1}\right)$ during the first day after litter treatments were applied and was above $1,100 \mathrm{~g} \mathrm{ha}^{-1} \mathrm{~h}^{-1}\left(1.0 \mathrm{lb} \mathrm{NH}_{3}-\mathrm{N}\right.$ $\mathrm{ac}^{-1} \mathrm{hr}^{-1}$ ) on the second day, losses that were higher than volatilization rates observed during the corresponding days in 2008. The reasons for this increased rate of $\mathrm{NH}_{3}$ volatilization in 2009 are difficult to identify with certainty because multiple factors, including manure composition, soil factors, and environmental conditions, affect the rate at which the $\mathrm{NH}_{3}$ is volatilized (Meisinger and Randall 1991; Meisinger and Jokela 2000). The increased rate was likely due in part to the fact that totalVPD measured over the first two days of the $\mathrm{NH}_{3}$ volatilization event was higher in $2009\left(3.41 \mathrm{kPa}\left[0.49 \mathrm{lb} \mathrm{in}^{-2}\right]\right)$ than in $2008\left(3.04 \mathrm{kPa}\left[0.44 \mathrm{lb} \mathrm{in}^{-2}\right]\right)$, but the effect of VPD may have also been combined with other factors. Ammonia losses from the disked litter treatment did not change much from 2008 to 2009 , but initial rates of $\mathrm{NH}_{3}$ loss from subsurface (injected) litter were actually near zero in 2009, lower than in 2008. As a result, the treatment effects on $\mathrm{NH}_{3}$ volatilization showed a larger contrast between litter application methods in 2009 than in 2008. In both years, the difference between treatments decreased each subsequent day after litter application, as cumulative losses removed most of the $\mathrm{NH}_{3}-\mathrm{N}$ from the surface litter, leaving smaller amounts available for further $\mathrm{NH}_{3}$ volatilization. By the fourth day after application of 2009 litter treatments, $\mathrm{NH}_{3}$ losses from surface litter were again only about twice as high as losses from subsurface litter.

Cumulative effects in 2009 showed that poultry litter application method affected $\mathrm{NH}_{3}$ volatilization even more strongly than the previous year, as more than 95\% of $\mathrm{NH}_{3}-\mathrm{N}$ applied on the surface was lost through volatilization within the first five days after poultry litter application (table 3). Disking the 2009 poultry litter into the soil decreased those losses to about $32 \%$, while subsurface application (injection) allowed an average of less than $8 \%$ of the applied $\mathrm{NH}_{3}-\mathrm{N}$ to volatilize. In other words, overall $\mathrm{NH}_{3}$ volatilization losses in 2009 were more than 12 times higher from surface-applied litter than 


\section{Table 2}

Total ammonia (as ammonium-nitrogen $\left[\mathrm{NH}_{4}-\mathrm{N}\right]$ ) loss in 2008 from poultry litter applied by injection, tilled in with shallow disking, or left on the surface. The individual comparison of $p$ values for inject vs disked is $p>0.087$, inject vs surface is $p<0.001$, and disked vs surface is $p<0.001$.

\begin{tabular}{llll}
\hline & \multicolumn{3}{l}{ Poultry litter application method } \\
\cline { 2 - 4 } & Injected $\left(\% \mathbf{N H}_{\mathbf{4}}-\mathbf{N}\right)$ & Disked $\left(\% \mathbf{N H}_{\mathbf{4}}-\mathbf{N}\right)$ & Surface $\left(\% \mathbf{~ H}_{\mathbf{4}} \mathbf{-} \mathbf{N}\right)$ \\
\hline \multirow{3}{*}{ Mean } & 7.8 & 21.5 & 78.5 \\
& 16.5 & - & 69.2 \\
& 12.1 & 21.5 & 73.9 \\
\hline
\end{tabular}

\section{Table 3}

Total ammonia loss in 2009 from poultry litter applied by injection, tilled in with shallow disking, or left on the surface. The individual comparisons of $p$ values for inject vs disked, inject vs surface, and disked vs surface are all $p<0.001$.

\begin{tabular}{|c|c|c|c|}
\hline & \multicolumn{3}{|c|}{ Poultry litter application method } \\
\hline & Injected $\left(\% \mathrm{NH}_{4}-\mathrm{N}\right)$ & Disked $\left(\% \mathrm{NH}_{4}-\mathrm{N}\right)$ & Surface $\left(\% \mathrm{NH}_{4}-\mathrm{N}\right)$ \\
\hline & 7.4 & 32.4 & 95.2 \\
\hline & 8.3 & & \\
\hline Mean & 7.9 & 32.4 & 95.2 \\
\hline
\end{tabular}

from subsurface (injected) litter and were more than 4 times higher from disked-in litter than from subsurface litter. These results were very similar to those from research studies on perennial grassland that also showed subsurface application of poultry litter prevented more than $90 \%$ of $\mathrm{NH}_{3}$ loss when compared to surface-applied poultry litter (Moore et al. 2011; Pote et al. 2011). In Sweden, Rodhe and Karlsson (2002) applied broiler manure in May 1998 after using a harrow to break the soil surface, and found that about 39\% of the $\mathrm{NH}_{3}-\mathrm{N}$ from the surface-applied manure was volatilized after five days, whereas incorporating the manure into the soil effectively prevented $\mathrm{NH}_{3}$ volatilization. However, the Swedish study had more than $3 \mathrm{~cm}$ (1 in) of precipitation and average air temperatures of only $12.3^{\circ} \mathrm{C}$ $\left(54.1^{\circ} \mathrm{F}\right)$, so the relatively low rates of $\mathrm{NH}_{3}$ loss they observed may have been largely due to lowerVPD.

\section{Summary and Conclusions}

Poultry litter application method greatly affected the volatilization of $\mathrm{NH}_{3}-\mathrm{N}$ from this conservation tillage system. When compared to conventional surface spreading of poultry litter, $\mathrm{NH}_{3}$ volatilization decreased an average of $67 \%$ when the litter application was lightly disked into the soil surface and decreased an average of $88 \%$ when the litter was applied below the soil surface using the Subsurfer prototype. These reductions in $\mathrm{NH}_{3}$ volatilization were achieved while retaining average ground cover of $82 \%$, consistent with conservation tillage needs, so further development of the Subsurfer technol- ogy could provide an effective management option to help farmers prevent $\mathrm{NH}_{3}-\mathrm{N}$ losses from conservation tillage systems.

\section{Acknowledgements}

We gratefully acknowledge the valuable assistance with field operation by Stephen M. Haller, biological science technician in Booneville, Arkansas; and by Dan Shirley and Ted Courier, farm managers in Beltsville, Maryland. We also thank Sara McQueeney and Barry Francis, chemists in Beltsville, Maryland, for their excellent ammonia analysis.

\section{Disclaimer} is solely for the purpose of providing specific information and does not imply recommendation or endorsement by the USDA.

\section{References}

Brady, N.C. 1990. The Nature and Properties of Soils, 10th ed. New York; Macmillan Publishing.

Battye, R., W. Battye, C. Overcash, and S. Fudge. 1994 Development and Selection of Ammonia Emission Factors: Final Report. EC/R Inc. Durham, NC. EPA Contract Rep. 68-D3-0034. Research Triangle Park. Durham, NC; US Environmental Protection Agency.

Brinson, S.E., Jr., M.L. Cabrera, and S.C. Tyson. 1994. Ammonia volatilization from surface-applied, fresh and composted poultry litter. Plant and Soil 167:213-218.

Brunke, R., P. Alvo, P. Schuepp, and R. Gordon. 1988. Effect of meteorological parameters on ammonia loss from manure in the field. Journal of Environmental Quality 17:431-436

Cabrera, M.L., S.C. Chiang, W.C. Merka, S.A. Thompson, and O.C. Pancorbo. 1993. Nitrogen transformations in surface-applied poultry litter: Effect of litter physical characteristics. Soil Science Society of America Journal 57:1519-1525
Mention of trade names or commercial products in this article
Cabrera, M.L., and S.C. Chiang. 1994. Water content effect on denitrification and ammonia volatilization in poultry litter. Soil Science Society of America Journal 58:811-816

Chapman, S.L., and C.S. Snyder. 1992. Soils and fertilizers. Information Article 2-92.Little Rock, AR: University of Arkansas Cooperative Extension Service.

CTIC (Conservation Tillage Information Center). 2004. National Survey of Conservation Tillage Practices., West Lafayette, IN: Conservation Tillage Information Center. http://www.ctic.purdue.edu/CTIC/CRM.html.

Dell, C.J., P.J.A. Kleinman, J.P. Schmidt, and D.B. Beegle. 2012. Low-disturbance manure incorporation effects on ammonia and nitrate loss. Journal of Environmental Quality 41:928-937.

Edwards, D.R., and T.C. Daniel. 1993. Effects of poultry litter application rate and rainfall intensity on quality of runoff from fescuegrass plots. Journal of Environmental Quality 22:361-365.

Fisher, D.C., and M. Oppenheimer. 1991. Atmospheric nitrogen deposition and the Chesapeake Bay estuary. Ambio 23:201-208.

Hansen, M.N., S.G. Sommer, and N.P. Madsen. 2003. Reduction of ammonia emission by shallow slurry injection: Injection efficiency and additional energy demand. Journal of Environmental Quality 32:1099-1104.

Howell, T.A., and D.A. Dusek. 1995. Comparison of vaporpressure-deficit calculation methods - Southern High Plains. Journal of Irrigation and Drainage Engineering 121(2):191-198.

Hutchinson, G.L., and F.G. Viets, Jr. 1969. Nitrogen enrichment of surface water by absorption of ammonia volatilized from cattle feedlots. Science 166:514-515.

Levine, S.L., and D.W. Schindler. 1989. Phosphorus, nitrogen, and carbon dynamics of experimental lake 303 during recovery from eutrophication. Canadian Journal of Fisheries and Aquatic Sciences 46:2-10.

Lockyer, D.R. 1984. A system for the measurement in the field of losses of ammonia through volatilization. Journal of the Science of Food and Agriculture 35(8):837-848.

Lockyer, D.R., B.F. Pain, and J.V. Klarenbeek. 1989. Ammonia emission from cattle, pig, and poultry wastes applied to pasture. Environmental Pollution 56:19-30.

Marshall, S.B., C.W. Wood, L.C. Braun, M.L. Cabrera, M.D. Mullen, and E.A. Guertal. 1998. Ammonia volatilization from tall fescue pastures fertilized with broiler litter. Journal of Environmental Quality 27:1125-1129.

Meisinger, J.J., and W.E. Jokela. 2000. Ammonia volatilization from dairy and poultry manure. NRAES Publication \#130: Managing nutrients and pathogens from animal agriculture. Ithaca, NY: Natural Resource, Agriculture, and Engineering Service.

Meisinger, J.J., A.M. Lefcourt, and R.B. Thompson. 2000. Construction and validation of mobile wind tunnels for studying ammonia volatilization. Applied Engineering in Agriculture 17(3):375-381. 
Meisinger, J.J., and G.W. Randall. 1991. Estimating nitrogen budgets for soil crop systems. In Managing Nitrogen for Groundwater Quality and Farm Profitability. Proceedings of Symposium by American Society of Agronomy, Anaheim, California, November 30, 1988,85-124. Madison, WI: Soil Science Society of America.

Mitchell, C.C., and J.O. Donald. 1995. The value and use of poultry manures as fertilizer. Alabama Cooperative Extension System Circular ANR-244. Auburn, AL:Alabama Cooperative Extension System.

Moal, J.F., J. Martinez, F. Guiziou, and C.M. Coste. 1995 Ammonia volatilization following surface-applied pig and cattle slurry in France. Journal of Agricultural Science (Cambridge) 125(2):245-252.

Moore, P.A., Jr., D.M. Miles, R.T. Burns, D.H. Pote, W.K. Berg, and I.H. Choi. 2011. Ammonia emissions factors from broiler litter in barns in storage, and after land application. Journal of Environmental Quality 40:1395-1404

Morrison, J.E., Jr., C. Huang, D.T. Lightle, and C.S.T. Daughtry. 1993. Residue measurement techniques. Journal of Soil and Water Conservation 48(6):478-483.

Nathan, M.V., and G.L. Malzer. 1994. Dynamics of ammonia volatilization from turkey manure and urea applied to soil. Soil Science Society of America Journal 58:985-990.

Pain, B.F, R.B.Thompson,Y.R. Rees, and J.H. Skinner. 1990. Reducing gaseous losses of nitrogen from cattle slurry applied to grassland by the use of additives. Journal of the Science of Food and Agriculture 50(2):141-153.

Peters, J., S.H. Combs, B. Hoskins, J. Jarman, J.L. Kovar, M.E. Watson, A.M. Wolf, and N. Wolf. 2003. Recommended methods of manure analysis. Extension Service, University of Wisconsin, Publication no. A3769.Madison, WI; University of Wisconsin Extension Service.

Pfluke, P.D., W.E. Jokela, and S.C. Bosworth. 2011. Ammonia volatilization from surface-banded and broadcast application of liquid dairy manure on grass forage. Journal of Environmental Quality 40:374-382.

Pote, D.H., W.L. Kingery, G.E. Aiken, F.X. Han, P.A. Moore, Jr., and K. Buddington. 2003. Water-quality effects of incorporating poultry litter into perennial grassland soils. Journal of Environmental Quality 32:2392-2398.

Pote, D.H., T.R. Way, P.J.A. Kleinman, P.A. Moore, Jr., J.J. Meisinger, K.R. Sistani, L.S. Saporito, A.L. Allen, and G.W. Feyereisen. 2011. Subsurface application of poultry litter in pasture and no-till soils. Journal of Environmental Quality 40:402-411.

Powell, J.M., W.E. Jokela, and T.H. Misselbrook. 2011. Dairy slurry application method impacts ammonia emission and nitrate leaching in no-till corn silage. Journal of Environmental Quality 40:383-392.
Rodhe, L., and S. Karlsson. Ammonia emissions from broiler manure: Influence of storage and spreading method. Biosystems Engineering 82(4):455-462.

Schroder, H. 1985. Nitrogen losses from Danish agriculture: Trends and consequences. Agriculture, Ecosystems \& Environment 14:279-289.

Sharpe, R.R., H.H. Schomberg, L.A. Harper, D.M. Endale, M.B. Jenkins, and A.J. Franzluebbers. 2004. Ammonia volatilization from surface-applied poultry litter under conservation tillage management practices. Journal of Environmental Quality 33:1183-1188.

Snedecor, G.W., and W.G. Cochran. 1980. Statistical methods, 7th ed. Ames, IA: Iowa State University Press.

Sommer, S.G., and A.K. Ersbøll. 1994. Soil tillage affects on ammonia volatilization from surface-applied or injected animal slurry. Journal of Environmental Quality 23(3):493-498

Sommer, S.G., and N.J. Hutchings. 2001. Ammonia emission from field applied manure and its reduction. European Journal of Agronomy 15:1-15.

Sommer, S.G., and J.E. Olesen. 1991. Effects of dry matter content and temperature on ammonia loss from surfaceapplied cattle slurry. Journal of Environmental Quality 20(3):679-683

Sommer, S.G., J.E. Olesen, and B.T. Christensen. 1991 Effects of temperature, wind speed and air humidity on ammonia volatilization from surface applied cattle slurry. Journal of Agricultural Science 117(1):91-100.

Thompson, R.B., and J.J. Meisinger. 2002. Management factors affecting ammonia volatilization from landapplied cattle slurry in the Mid-Atlantic USA. Journal of Environmental Quality 31(4):1329-1338.

Thompson, R.B., J.C. Ryden, and D.R. Lockyer. 1987. Fate of nitrogen in cattle slurry following surface application or injection to grassland. Journal of Soil Science 38:689-700.

USDA NRCS (Natural Resources Conservation Services). 2011. Conservation Practice Standard for Mulch Tillage, code 345. US Department of Agriculture Natural Resources Conservation Service. http://efotg.sc.egov. usda.gov/references/public/SD/345.pdf.

Van Breemen, N., P.A. Burrough, E.J. Velthorst, H.F van Dobben, T. de Wit, T.B. Ridder, and H.F.R Reijnders. 1982. Soil acidification from atmospheric ammonium sulphate in forest canopy through fall. Nature 299:548-550.

Wulf, S., M. Maeting, and J. Clemens. 2002. Application technique and slurry co-fermentation effects on ammonia, nitrous oxide, and methane emissions after spreading: I. ammonia volatilization. Journal of Environmental Quality 31:1789-1794. 